\title{
LAND USE AND OCCUPATION ANALYSIS OF PERMANENT PRESERVATION AREAS IN LAVRAS COUNTY, MG
}

\author{
Análise do uso e ocupação da terra em áreas de preservação permanente \\ no município de Lavras, MG
}

\author{
Aliny Aparecida dos Reis ${ }^{1}$, Marcelo Dias Teixeira ${ }^{2}$, Fausto Weimar Acerbi Júnior², \\ José Marcio de Mello², Lucilia Rezende Leite ${ }^{2}$, Sérgio Teixeira da Silva²
}

\begin{abstract}
The Permanent Preservation Areas (PPAs) are considered essential for the maintenance of local biodiversity, so that your protection is regulated by the Brazilian legislation. This work had the objective of delimiting permanent preservation areas according to determinations of the current Brazilian environmental legislation, and identify the occurrence of conflict between the land use and legislation in Lavras county, MG, by combination of technologies of remote sensing and geographic information systems. The PPAs correspond to $42.33 \%$ of Lavras county's territory. The conflict between the land use and environmental legislation occurs in $63.48 \%$ of PPAs' territory, mainly corresponding to the pasture areas, bare soil and agriculture. The PPAs of tops of hills showed the highest conflicts with the legislation, with $48.48 \%$ of the territory occupied by pastures, and $13.62 \%$ by agriculture. The PPAs located in the surrounding of water courses and in the slopes with declivity higher than $45^{\circ}$ presented $59.99 \%$ and $92.03 \%$, respectively of the territory occupied by native vegetation of semi-deciduous forest and natural fields.
\end{abstract}

Index terms: Environmental legislation, land cover, geoprocessing.

\section{RESUMO}

As Áreas de Preservação Permanente (APPs) são consideradas essenciais para a manutenção da biodiversidade local, de modo que a sua proteção é regulamentada pela legislação brasileira. Neste trabalho, objetivou-se delimitar as áreas de preservação permanente de acordo com as determinações da legislação ambiental brasileira vigente, e identificar a ocorrência de conflito entre o uso da terra e a legislação no município de Lavras, MG, mediante a combinação de tecnologias de sensoriamento remoto e sistemas de informações geográficas. As APPs correspondem a 42,33\% do território do munícipio de Lavras. O conflito entre o uso da terra e a legislação ambiental ocorre em $63,48 \%$ do território das APPs, correspondendo principalmente as áreas de pastagem, solo exposto e agricultura. As APPs de topos de morro foram as que apresentaram maiores conflitos com a legislação, com 48,48\% do seu território ocupado por pastagens e 13,62\% ocupado pela agricultura. As APPs localizadas no entorno dos cursos d'água e nas encostas com declividade superior a $45^{\circ}$ apresentaram, respectivamente, $59,99 \%$ e $92,03 \%$ do seu território ocupados por vegetação nativa de floresta semidecídua e campos naturais.

Termos para indexação: Legislação ambiental, cobertura da terra, geoprocessamento.

\section{(Received in april 27, 2012 and approved in may 31, 2012)}

\section{INTRODUCTION}

The fast population growth associated with the fast agricultural and industrial expansion caused a severe ecosystem degradation in the whole planet, reflecting on the quality of life of the populations and stability of natural resources (REIS et al., 2009). The expansion of new agricultural frontiers causes partial removal of the natural vegetation cover by areas destined to agriculture and pasture, changing natural ecosystems into an agrosystem (BOLFE et al., 2008).

The necessity of governmental policies that ensure the agricultural production and preservation of the environment is essential to the maintenance of natural ecosystems. On this regard, the Brazilian Forestry Code, (BRASIL, 2012) set up as Permanent Preservation Areas (PPAs) those covered or not by native vegetation, with the environmental role of preserving the water resources, the landscape, the geological stability, the biodiversity, the gene flow of fauna and flora, protecting the soil and ensuring the well-being of human populations.

The permanent preservation areas are located in several strategic environmental viewpoints (REIS et al., 2009). In small and large rural properties, the PPAs of top

'Universidade Federal de Lavras/UFLA - Departamento de Ciências Florestais/DCF - Cx. P. 3037 - $37200-000$ - Lavras - MG - Brasil alinyreis@hotmail.com

¿2Universidade Federal de Lavras/UFLA - Departamento de Ciências Florestais/DCF - Lavras - MG - Brasil 
of hills, along water courses and in the slopes with declivity higher than $45^{\circ}$ are extremely important points, which in the majority of the cases are occupied by agriculture, but mainly by pastures that in most cases are in degradation process (NASCIMENTO et al., 2005; SILVA et al., 2010).

The PPAs are constantly submitted to anthropic pressures where it is observed is a substitution process of natural landscapes by other types of land use and occupation. Additionally, areas with native forest are converted to forest fragments, being these, responsible for the maintenance of natural resources essential for living and the maintenance of balance in the environments which they are involved (EUGENIO et al., 2011).

The process of land use and occupation is strongly associated with social, economic and cultural practices specific of each region (DI GREGORIO, 2005). Since each constituent of land cover can be determined through spectral, textural, shape and context attributes, thus enabling, by geoprocessing techniques the direct extraction of information contained in the landscape and the mapping of land cover (BOTELHO; CENTENO, 2005; FERREIRA et al., 2005).
The use of geoprocessing techniques brought out as an auxiliary alternative for the effective compliance of the Brazilian environmental legislation, enabling delimitation and investigation of suitability of the land use in permanent preservation areas, corroborating with studies developed by Nascimento et al. (2005), Reis et al. (2009), Silva et al. (2010), Eugenio et al. (2011), Soares et al. (2011).

In this context, the current work had the objective of delimiting the permanent preservation areas according to determinations of Brazilian environmental legislation in force, and identifying the occurrence of conflict between the land use and legislation in Lavras, MG, by combination of technologies of remote sensing and geographic information systems.

\section{MATERIAL AND METHODS}

\section{Location and characteristics of the study area}

The study area corresponds to the Lavras county, located in the Southern region of the state of Minas Gerais, whose geographical coordinates are $21^{\circ} 13^{\prime} 35^{\prime \prime} \mathrm{S}, 44^{\circ} 58^{\prime} 43^{\prime \prime}$ $\mathrm{W}$ and altitude of 918 meters, and an approximate area of 56371 ha (Figure 1).

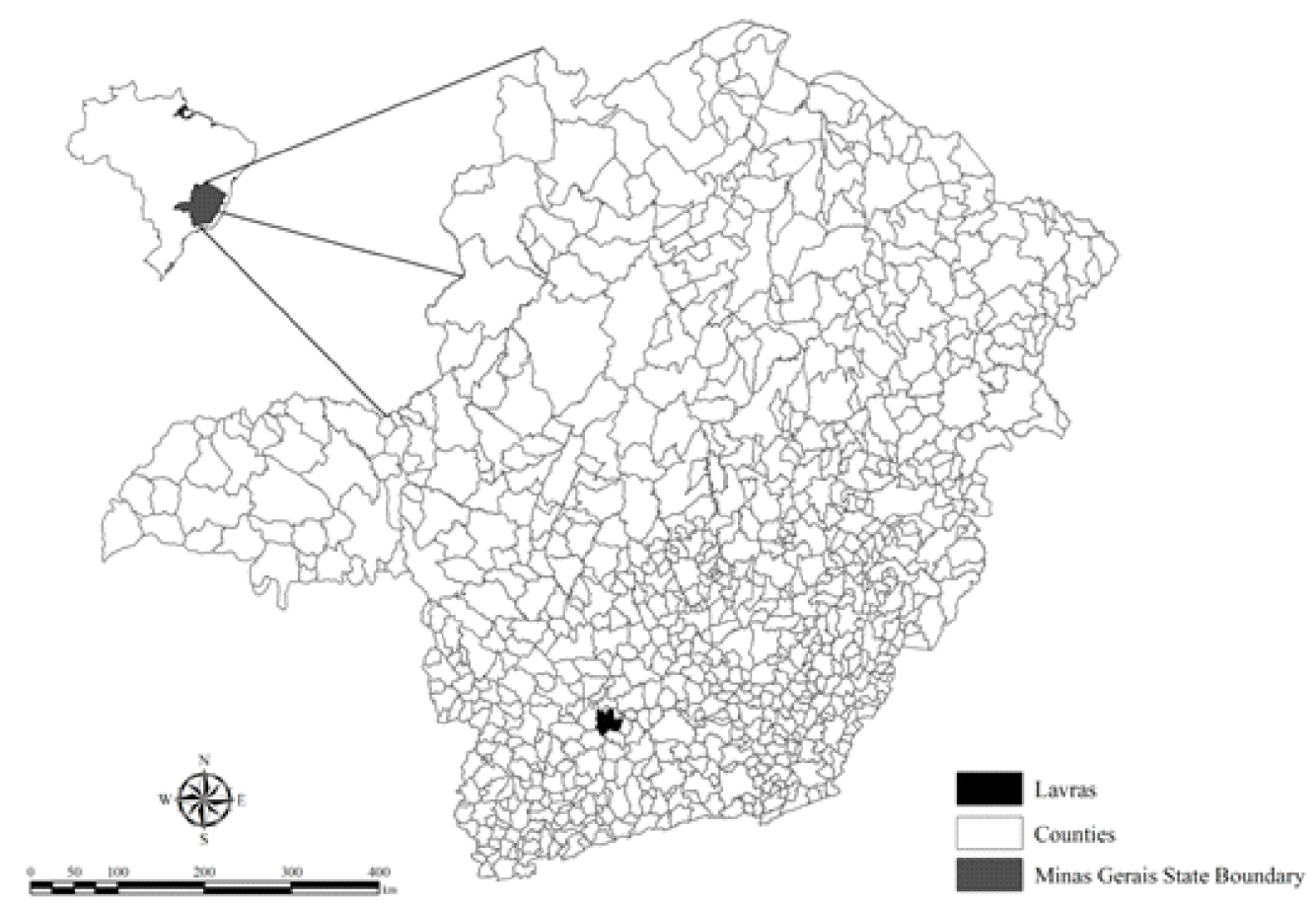

Figure 1 - Geographical localization of the Lavras county, MG. 
The climate in Lavras, according to the climate classification of Köeppen, is Cwa, temperate and rainy with dry winter and rainy summer, and annual average temperature around $19.4^{\circ} \mathrm{C}$. The annual precipitation is usually of $1530 \mathrm{~mm}$, the total evaporation of the year equal to $1343 \mathrm{~mm}$ and the annual relative humidity of $76 \%$ (SPAROVEK et al., 2007).

Lavras is located in the basin of Alto Rio Grande, being cut by three main rivers: Cervo, Capivari and Grande. The forest formation characteristic of the region is the Montane Seasonal Semideciduous Tropical Forest (CARVALHO; SCOLFORO, 2008).

\section{Development of the Hydrologically Consistent Digital Elevation Model}

The data used for generating the Hydrologically Consistent Digital Elevation Model (HCDEM) were the cartographic and planialtimetric bases in digital format in the scale of 1:50000, scanning from the leaves SF-23-V-DIII-2, SF-23-V-D-III-4, SF-23-X-C-I-1 e SF-23-X-C-I-3 (Instituto Brasileiro de Geografia e Estatística - IBGE, 1977), containing the urban areas, roads, hydrography and contour lines with equidistance of 20 meters for the Lavras.

In order to determine the lowest dimension of land represented in the map, that is, the spatial resolution of the cells of HCDEM, the cartographic accuracy of $0.2 \mathrm{~mm}$ was multiplied by scaling factor, resulting in a dimension of 10 meters for the output cell.

The HCDEM for the Lavras county was generated using the algorithm of interpolation topo to raster (Environmental Systems Research Institute - ESRI, 2006). The necessary operations for generating HCDEM demanded the orientation of watershed mesh in the direction of the drainage and the adjust from altimetry to hydrography.

In order to identify and eliminate possible imperfections in the HCDEM, such as spurious depressions, post-processing operations were realized. The spurious depressions interrupt the superficial water draining, generate imperfections in the model whose drainage must be converged up to the mouth hydrography (MACHADO et al., 2010). Therefore, these depressions must be removed so that the Digital Elevation Model (DEM) will be consistent hydrological.

\section{Delimitation of the Permanent Preservation Areas (PPAs)}

The PPAs' delimitation was realized according to the methodology proposed by Peluzio et al. (2010), implemented adopted base on HCDEM. The categories of PPAs were established according to the specifications in the art. $2^{\circ}$ and $3^{\circ}$ Resolution $n^{\circ} 303 / 2002$ of CONAMA (Conselho Nacional do Meio Ambiente - CONAMA, 2002).

The preservation areas in the surrounding springs (PPA-1) were demarcated delimiting a radius of preservation of 50 meters. The springs were extracted from the hydrographic network in the letters of IBGE in the scale of 1:50000 (IBGE, 1977), considering in each extremity there is a spring.

The preservation areas corresponding to slopes with declivity higher than $45^{\circ}$ or $100 \%$ (PPA-2) were delimited using HCDEM. Firstly, a matrix map of declivity of the area studied was drawn up. After that, the reclassification of the map of declivity was realized in order to delimit only the areas with declivity higher than $45^{\circ}$, corresponding to PPAs.

The demarcation of the PPAs along the water courses (PPA-3) was realized using the database corresponding to the hydrographic network (IBGE, 1977). For simple margin watercourses, with up to $10 \mathrm{~m}$ wide, it was delimited a preservation area of $30 \mathrm{~m}$ on each side. For double margin watercourses, the average width was determined measuring it directly from the RapidEye images, delimiting on each side a preservation area of $50 \mathrm{~m}$ for streams with an average width between $10 \mathrm{~m}$ and $50 \mathrm{~m}$, and $100 \mathrm{~m}$ for streams with an average width between $50 \mathrm{~m}$ and $200 \mathrm{~m}$, according to the methodology used by Silva (2011).

The preservation areas located at the top of the hills (PPA-4) were delimited following the specifications in the art. $2^{\circ}$ and $3^{\circ}$ Resolution $n^{\circ} 303 / 2002$ of CONAMA (CONAMA, 2002), which hills are considered those with height between $50 \mathrm{~m}$ and $300 \mathrm{~m}$ and with declivity higher than $30 \%$, and in case of occurring two or more hills or mountains whose summit are separated by distances lower than 500 meters, the PPA will cover the set of hills and mountains, delimited from the contour line corresponding to $2 / 3$ of the height in relation to the hill or mountain base with lower height in the set.

For demarcating PPA-4, it was done the inversion of the direction for the drainage of HCDEM by reclassification of values that represent the direction of drainage, and the cells correspond to hydrography were eliminated with the objective of ensuring the depressions situated on these were not identified. Considering the inversion of direction of the drainage, the tops of hills were identified as depressions, thus, the hill base was identified as the area of drained contribution by a depression. Thus, the altitudes of the base and top were determined by the identifications, respectively, the lowest and highest value of cells altitude of HCDEM, which represent the hill, and the height was determined by the difference between the altitude of the top of the hill and altitude of the base. 
The hills with height between 50 and 300 meters and with declivity higher than $30 \%$ were selected, and the preservation areas were delimited calculating the relation between the height of each cell and the height of the cell with highest altitude for all cells of HCDEM. The cells that have relation equal or superior to $2 / 3$ corresponded to PPAs situated in the top of the hill.

\section{Mapping of cover classes and land use}

In the elaboration of the thematic map of the Lavras county four RapidEye images were used corresponding to the scenes 2329214, 2329215, 2329314 and 2329315 from 08/ $04 / 2009$ and $08 / 10 / 2009$ with spatial resolution of 5 meters and blue $(440-510 \mathrm{~nm})$, green $(520-590 \mathrm{~nm})$, red $(630-685 \mathrm{~nm})$, red-edge $(690-730 \mathrm{~nm})$ and near infrared $(760-850 \mathrm{~nm})$ spectrum bands. The RapidEye images are commercialized with pre-processing corresponding to a geometric correction form of high precision. From these images a geoferenced mosaic was constructed corresponding to the study area.

The mapping of the land cover and use was obtained through object-oriented classification using the ECognition Developer 8.0 software (ECOGNITION, 2009). For the segmentation of the image, the multiresolution algorithm was used, which uses criteria of homogeneity, besides a scale parameter in order to delimit the complex objects that make up the landscape (ECOGNITION, 2009). Thus, it is possible to group near pixels with similar attributes in regions or objects, this is a fact that provides a higher number of descriptors, increasing the number of input variables in the classification process (BOTELHO; CENTENO, 2005).

In the digital image classification process, the algorithm of the nearest neighbor was used, based on the spectral characteristics of 5 bands and NDVI of each object and also other attributes were taken into account, such as brightness, the average of band 5 , the maximum difference for the 5 bands and shape descriptors.

As a post classification technique, the map accuracy was calculated based on 620 samples collected randomly from the county and verified in the field. This information was compared with the classification results through a confusion matrix and Kappa coefficient. The confusion matrix shows the number of objects correctly classified in opposition to the number of objects estimated for each class through the classification. This matrix enables to obtain information of the overall accuracy, per class accuracies, and Kappa coefficient.

\section{Analyses of conflicts of land use}

For identifying and analyzing the conflicts of land use in the areas intended to the preservation, it was realized the overlapping of thematic cover maps and land use and the categories of PPAs, using the command identity available at the module Arc Toolbox of the ArcGis 9.3 software (ESRI, 2006), thus locating the intersection areas, corresponding to conflicting areas in each category of PPA.

\section{RESULTS AND DISCUSSION}

\section{Permanent Preservation Areas}

Figure 2 and table 1 showed respectively, the spatial distribution and area occupied for each category of PPA in Lavras county.

The areas surrounding the springs, corresponding to PPA-1, represent $1.34 \%$ of the county area and totalize $756.07 \mathrm{ha}$. These areas are essential for maintaining the quality and amount of water for the springs, directly influencing the storage of groundwater and the water courses patterns (MENEZES et al., 2009).

Lavras county has most of its relief classified as from strong wavy to mountainous, corresponding to areas with declivity between $20^{\circ}$ and $40^{\circ}$. The PPA-2, corresponding to preservation areas with declivity higher than $45^{\circ}$ occupies an area of 0.63 ha, equivalent to $0.001 \%$ of the total area of the county. Due to the fact of its relief be rough, the county has an extensive area occupied by PPAs of the top of the hill (PPA-4), which totalizes 17056.21 ha and represents $30.26 \%$ of the county area. In these areas an accute necessity of protection is verified, once in areas with declivity higher than $20^{\circ}$, the accute relief makes the superficial drainage fast in most soils, and may cause serious problems of erosion and undertake the sustainable development of the county (CARDOSO et al., 2006).

The PPAs along the water courses (PPA-3) occupy the most sensitive areas of a hydrographical basin and ensure the stabilization of the riverbanks, being considered extremely important for the water quality control for reducing the occurrence of superficial drainage, which can cause erosion and nutrient carryover, chemical products and sediments for the water courses (EUGENIO et al., 2011). The area occupied by these PPAs is of 6908.02 ha, which represents $12.25 \%$ of the total area of the county.

It is also observed that all classes of PPAs together occupy an area of 23859.70 ha, of a total of 56371.68 ha of the county's area, representing $42.33 \%$ of areas legally protected. Silva et al. (2010) studying the PPAs in Itabira county, MG, found out that the areas intended to preservation occupies $42.39 \%$ of the total area of the county. In a study developed by Soares et al. (2011) in Viçosa county, MG, $54.15 \%$ of the area was mapped out as PPAs, corroborating the presence of anthropic activity in PPAs will inevitably occupy a significant area of the counties, causing disagreement with the legislation. 


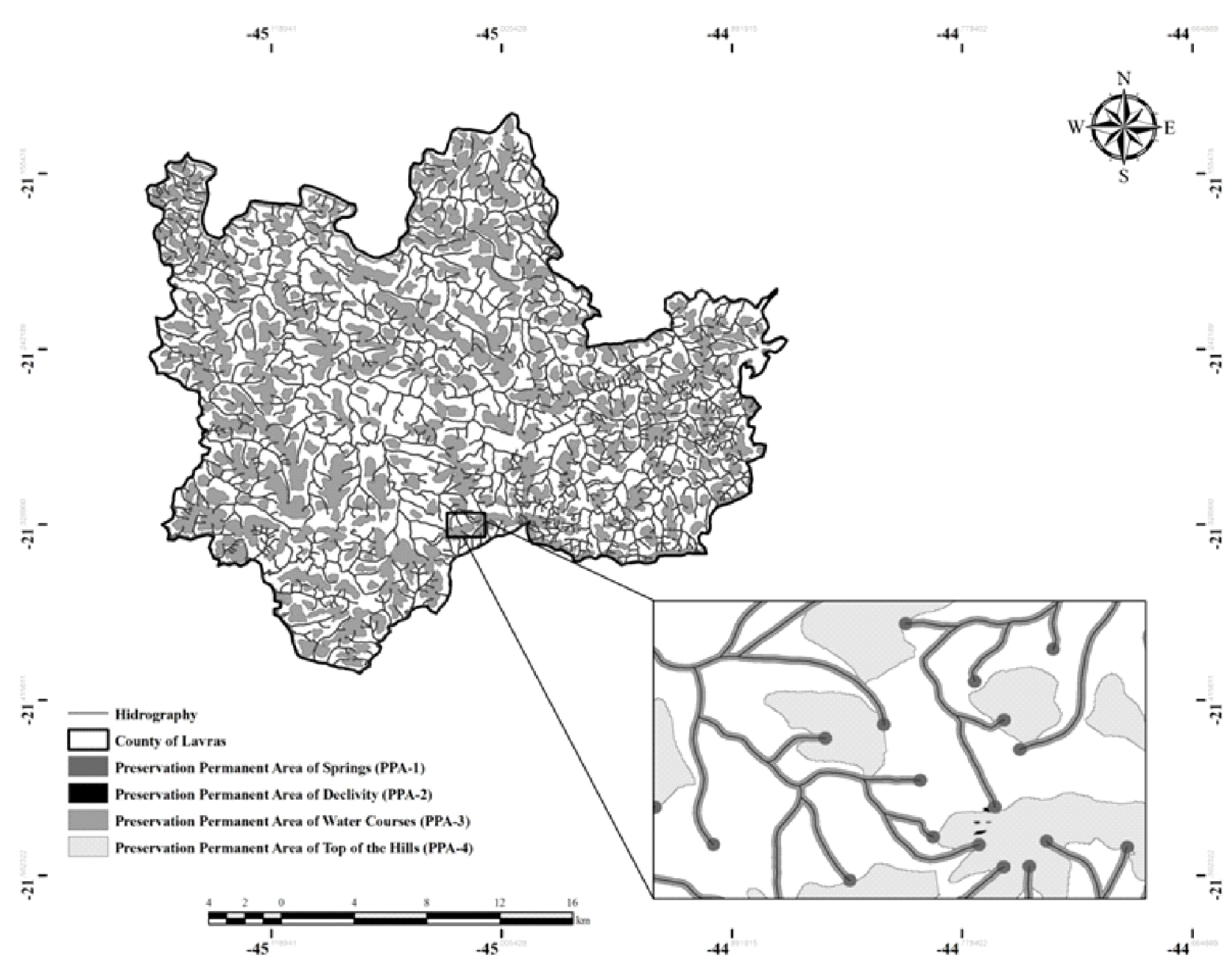

Figure 2 - Spatial distribution of the categories of PPAs in Lavras county, MG.

Table 1 - Percentage of areas occupied by PPAs in Lavras county, MG.

\begin{tabular}{ccrc}
\hline PPAs & Description & Area (ha) & \% (area occupied in the county) \\
\hline PPA-1 & Radius of $50 \mathrm{~m}$ & 756.07 & 1.34 \\
PPA-2 & Declivity higher than $45^{\circ}$ & 0.63 & 0.001 \\
PPA-3 & 30,50 or $100 \mathrm{~m}$ & 6908.02 & 12.25 \\
PPA-4 & Upper third of the hills & 17056.21 & 30.26 \\
Total & Without overlapping & 23859.70 & 42.33 \\
\hline
\end{tabular}

\section{Usage classes and Land Occupation}

The following land cover classes and soil use were mapped out: agriculture, water, built-up area, fields, reforestation, semi-deciduous forest, pasture and bare soil.

Figure 3 shows the location of the field samples used for the evaluation of the classification. The
Overall Accuracy and Kappa index values were respectively equal to 0.89 and 0.87 . According to Congalton and Green (2009) values of Kappa coefficient between 0.8 and 1.0 are considered excellent and indicate that the classification reached a satisfactory result. 


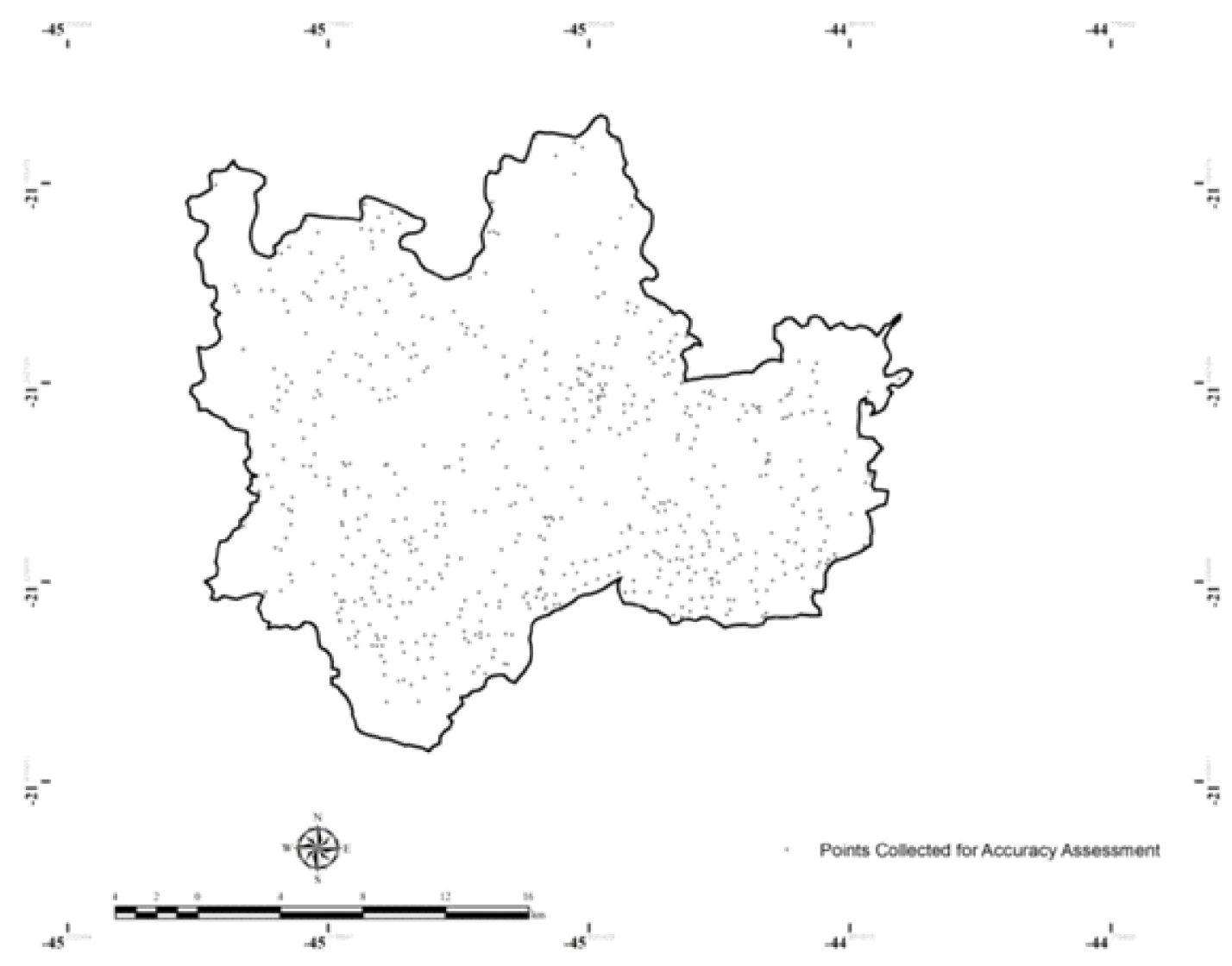

Figure 3 - Location of the field samples in Lavras county, MG.

\section{Land Use and Occupation in Permanent Preservation Areas}

Table 2 and figure 4 represent the land use and occupation in the areas intended to preservation in Lavras county. It is verified the biggest part of PPAs are occupied by pasture and semi-deciduous forest, corresponding to $42.67 \%$ and $23.27 \%$, respectively. The native fields occupy $12.94 \%$ of PPAs, while agriculture occupies $10.32 \%$ of the areas intended to preservation. The built-up area, the water, the reforestation and the bare soil occupy, respectively, $3.64 \%, 0.28 \%, 0.69 \%$ and $6.16 \%$ of PPAs.

The use conflict and land occupation in the areas intended to preservation corresponds to $63.48 \%$ of the territory of PPAs, highlighting the intensive anthropic activity in the areas legally protected by environmental legislation. According to Silva et al. (2010) the preservation of PPAs can be considered a sustainability indicator for the county due to the environmental role that these areas play in environments in which are involved.
Table 2 - Quantification of land cover and use in PPAs in Lavras county, MG.

\begin{tabular}{lrr}
\hline \multicolumn{1}{c}{ Usage Classes and Land } & \multicolumn{2}{c}{ PPAs } \\
\cline { 2 - 3 } \multicolumn{1}{c}{ Occupation } & Area (ha) & \multicolumn{1}{c}{$\%$} \\
\hline Agriculture & 2461.79 & 10.32 \\
Bare soil & 1469.68 & 6.16 \\
Built-up Area & 868.62 & 3.64 \\
Fields & 3087.81 & 12.94 \\
Pasture & 10180.63 & 42.67 \\
Reforestation & 164.27 & 0.69 \\
Semideciduos Forest & 5551.36 & 23.27 \\
Water & 65.85 & 0.28 \\
\hline Total & 23859.7 & 100 \\
\hline
\end{tabular}

The results of land use and occupation in each category of PPA are shown in table 3. It is observed that PPA-1, corresponding to areas of springs has $47.83 \%$ of the territory occupied by native vegetation of fields and

Ciênc. agrotec., Lavras, v. 36, n. 3, p. 300-308, maio/jun., 2012 
semi-deciduous forest. The pasture occupies $35.99 \%$ of the areas intended to preservation in the surrounding of the springs, this is a fact that can cause a big negative impact on the natural regeneration, besides providing the compaction of the soils and water contamination (EUGENIO et al., 2011). The agriculture and bare soil occupy together $12.73 \%$ of PPAs of the springs, which can be contributing for silting and contamination of the springs by soil tillage and use of pesticides. The rest of PPAs of the springs is occupied by reforestation $(0.70 \%)$, water $(0.03 \%)$ and builtup area (2.73\%). Pinto et al. (2004) studying the springs of the Santa Cruz stream in Lavras, MG, found higher flows in the springs protected by native vegetation in comparison to other land use such as pastures and agricultural crops. The presence of native vegetation surrounding springs provides increased infiltration of rainwater into the soil, and hence aquifer recharge and power of the springs, preventing the drained of the rain water into the bed of watercourses (MENEZES et al., 2009).

The PPA-2, corresponding to the slope areas has $92.03 \%$ of the territory occupied by native fields and $7.97 \%$ by pastures. The maintenance of native vegetation in areas with high inclination level ensures the preservation of the soil because the inadequate occupation of these areas causes a higher probability of landslides due to the fragility (CARDOSO et al., 2006).

The preservation areas corresponding to water courses (PPA-3) have $59.99 \%$ of their areas covered by native vegetation. The areas of pasture, agriculture and bare soil occupy, respectively, $26.98 \%, 5.20 \%$ and $4.34 \%$ of PPAs of water courses. The maintenance of vegetation in the surrounding of water courses ensures the protection of water resources, ecological integrity in the wetland areas, gene flow among entre remaining forest, providing food and shelter for fauna (BELLUTA et al., 2011). According to Fagundes e Gastal Jr. (2008) native forests occurring on the banks of the watercourses form corridors that effectively contribute to biodiversity conservation, being responsible for the connectivity among the remaining forest fragments. Nascimento et al. (2005), in Alegre, ES, found that the PPAs on the banks of the watercourses were $90.95 \%$ occupied by some kind of land use and only $9.05 \%$ were actually covered by forest fragments. Reis et al. (2009) found that only 8.70\% of the PPAs of the watercourses in Bandeirantes, PR, were covered by native forests, corroborating the intense human pressure on these environments.

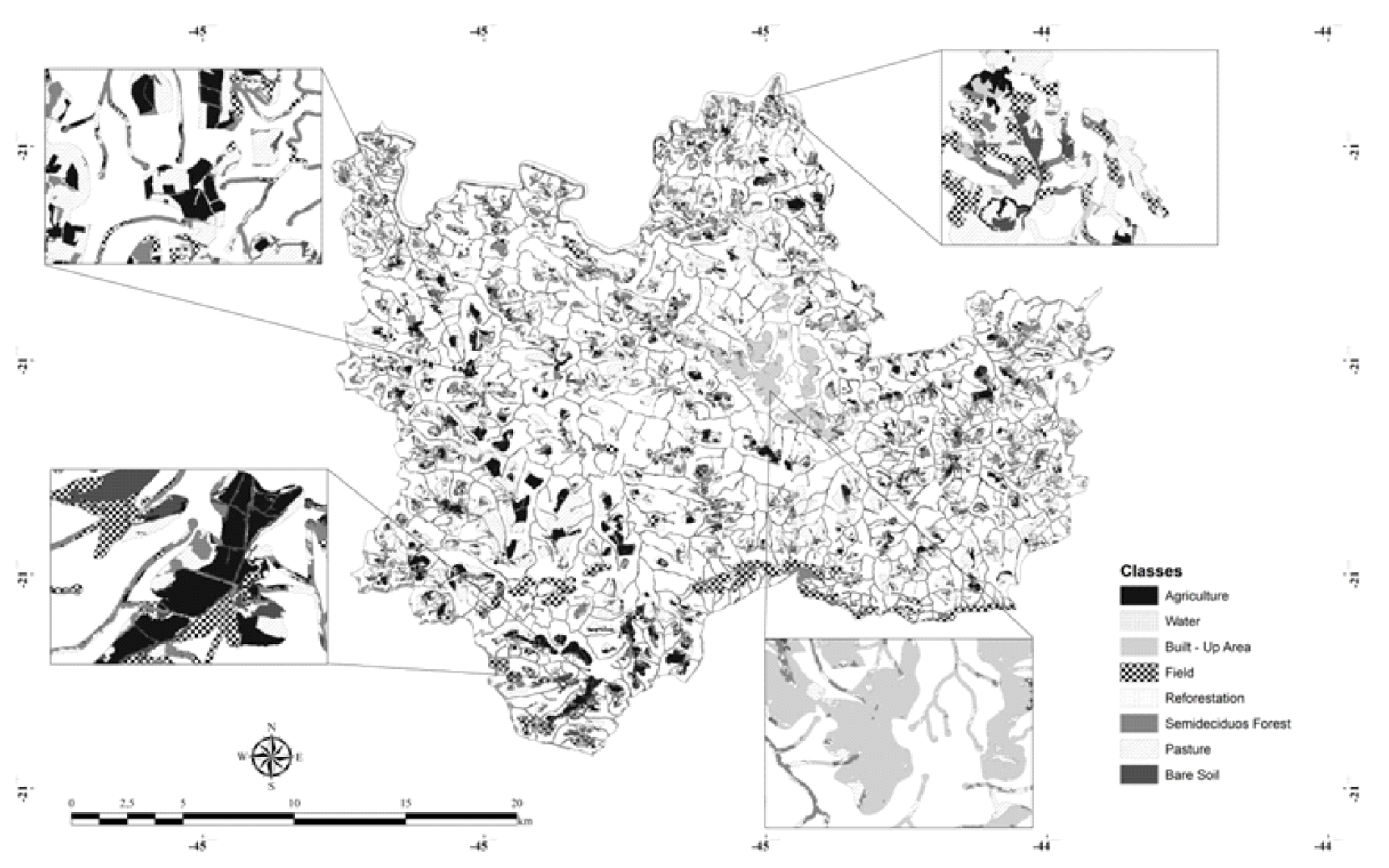

Figure 4 - Land use and cover in PPAs in Lavras county, MG.

Ciênc. agrotec., Lavras, v. 36, n. 3, p. 300-308, maio/jun., 2012 
Table 3 - Quantification of land cover and use in each category of PPA in Lavras county, MG.

\begin{tabular}{lcccccccc}
\hline \multirow{2}{*}{ Usage Classes and Land Occupation } & \multicolumn{2}{c}{ PPA-1 } & \multicolumn{2}{c}{ PPA-2 } & \multicolumn{2}{c}{ PPA-3 } & \multicolumn{2}{c}{ PPA-4 } \\
\cline { 2 - 9 } & Area (ha) & $\%$ & Area (ha) & $\%$ & Area (ha) & $\%$ & Area (ha) & $\%$ \\
\hline Agriculture & 57.28 & 7.58 & 0.00 & 0.00 & 365.69 & 5.20 & 2321.36 & 13.62 \\
Bare soil & 38.92 & 5.15 & 0.00 & 0.00 & 305.44 & 4.34 & 1152.62 & 6.76 \\
Built-up Area & 20.64 & 2.73 & 0.00 & 0.00 & 137.43 & 1.95 & 729.08 & 4.28 \\
Fields & 138.51 & 18.32 & 0.58 & 92.03 & 799.07 & 11.36 & 2281.59 & 13.39 \\
Pasture & 272.09 & 35.99 & 0.05 & 7.97 & 1897.96 & 26.98 & 8263.29 & 48.48 \\
Reforestation & 5.30 & 0.70 & 0.00 & 0.00 & 42.44 & 0.60 & 119.72 & 0.70 \\
Semideciduos Forest & 223.09 & 29.51 & 0.00 & 0.00 & 3420.42 & 48.63 & 2174.30 & 12.76 \\
Water & 0.24 & 0.03 & 0.00 & 0.00 & 65.27 & 0.93 & 1.25 & 0.01 \\
\hline Total & 756.07 & 100 & 0.63 & 100 & 7033.72 & 100 & 17043.22 & 100 \\
\hline
\end{tabular}

The PPA-4, corresponding to the areas of top of the hill has $48.48 \%$ of the territory occupied by pastures and $13.62 \%$ by agriculture. The natural fields and semi-deciduous forest occupy, respectively, $13.39 \%$ and $12.76 \%$ of PPAs' areas of the top of the hill. The rest of PPA- 4 is occupied by reforestation $(0.70 \%)$, water $(0.01 \%)$, built-up area $(4.28 \%)$ and bare soil $(6.76 \%)$. According to Ferreira et al. (2005) the forest native vegetation of the region of Alto Rio Grande, was reduced to remaining and sparse areas of semideciduous forest, mostly very disturbed by extensive farming and agriculture, once the occurrence coincides with the most humid and fertile soils, which are more aimed by farming.

\section{CONCLUSIONS}

The image processing and analysis techniques coupled with a geographic information system provided accurate information about the dimensions, spatial distribution and use and occupation of land in the PPAs.

The most common conflicting uses of the PPAs are areas with pasture, agriculture and bare soil. The PPAs located on top of the hill showed the greatest conflict between the legislation and land use classes.

The PPAs preserved are mainly concentrated in the surrounding of watercourses.

The presence of anthropic activity in permanent preservation areas will inevitably disagree with the legislation, since the PPAs represent a significant area of the of Lavras county.

\section{REFERENCES}

BELLUTA, I. et al. Aplicação de técnica de geoprocessamento em áreas degradadas de mata ciliar e sua correlação com qualidade da água numa sub-bacia hidrográfica. Irriga, Botucatu, v. 16, n. 2, p. 177-198, abr.jun. 2011.
BOLFE, E. L.; BOLFE, A. P. F.; SIQUEIRA, E. R. Dinâmica do uso e ocupação do solo: subsídio à recuperação de áreas degradadas em Japaratuba, SE. Geomática, Santa Maria, v. 3, n. 1 e 2, 2008.

BOTELHO, M. F.; CENTENO, J. A. S. Uso integrado de imagem de alta resolução espacial e altura derivada do laser scanner na escolha do classificador orientado a região. Boletim de Ciências Geodésicas, Curitiba, v. 11, n. 1, p. 71-87, jan./jun. 2005.

BRASIL. Lei n. 12.651, de 25 de maio de 2012. Institui o novo Código Florestal. Disponível em: <https:// www.planalto.gov.br/ccivil_03/_ato2011-2014/2012/lei/ 112651.htm>. Acesso em: 04 jun. 2012.

CARDOSO, C. A. et al. Caracterização hidroambiental da bacia hidrográfica do rio Debossan, Nova Friburgo, RJ. Revista Árvore, Viçosa, v.30, n.2, p.249-256, 2006.

\section{CARVALHO, L. M. T. de.; SCOLFORO, J. R. Inventário Florestal de Minas Gerais: Monitoramento da flora nativa 2005-2007. Lavras: Editora UFLA, 2008. 357p.}

CONGALTON, R. G., GREEN, K. Assessing the Accuracy of Remotely Sensed Data: Principles and Practices. $2^{\circ}$ Ed. CRC/Taylor \& Francis, Boca Raton, 2009. 183p.

CONSELHO NACIONALDO MEIOAMBIENTE. Resolução no 303, de 20 de março de 2002. Dispõe sobreparâmetros, definições e limites de Áreas de Preservação Permanente. Disponível em: <http:// www.mma.gov.br/port/conama/ legiabre.cfm?codlegi=299> . Acesso em: 7mar. 2012. 
DI GREGORIO, A. Land cover classification system (LCCS), version 2 - classification concepts and user manual. Rome: FAO, 2005. 208 p.

ECOGNITION. User guide 8. Definiens Imaging. Müchen, Germany, 2009. 236 p.

ENVIRONMENTALSYSTEMS RESEARCHINSTITUTE -ESRI. Inc. ArcGIS Professional: GIS for the desktop, versão 9.3. CA. 2006.

EUGENIO, F. C. et al. Identificação das áreas de preservação permanente no município de Alegre utilizando geotecnologia. Cerne, Lavras, v. 17, n. 4, p. 563-571, out./dez. 2011.

\section{FAGUNDES, N. A.; GASTALJÚNIOR, C. V. S.}

Diagnóstico ambiental e delimitação de Áreas de Preservação Permanente em um assentamento rural. Acta Scientiarum Biological Sciences, Maringá, v. 30, n. 1, p. 29-38, 2008.

FERREIRA, E. et al. Identificação de fragmentos de floresta nativa, por diferentes intérpretes, com a utilização de imagens Landsat e Cbers em Lavras, MG.

Ciência e Agrotecnologia, Lavras, v. 29, n. 3, p. 649-656, mai.jun. 2005.

\section{INSTITUTOBRASILEIRODE GEOGRAFIAE} ESTATÍSTICA - IBGE. Cartas topográficas: Lavras, Itumirim, Carmo da Cachoeira e Nepomuceno. Escala 1:50.000. 1977.

MACHADO, K. J. et al. Determinação automática da capacidade de armazenamento de um reservatório. Revista Brasileira de Cartografia, $n^{\circ}$ 62, Edição Especial 01, p. 239-245, 2010.

MENEZES, M. D. et al. Dinâmica hidrológica de duas nascentes, associada ao uso do solo, características pedológicas e atributos físico-hídricos na sub-bacia hidrográfica do Ribeirão Lavrinha - Serra da Mantiqueira
(MG). Scientia Forestalis, Piracicaba, v. 37, n. 82, p. 175184, jun. 2009.

NASCIMENTO, M. C. et al. Uso do geoprocessamento na identificação de conflito de uso da terra em áreas de preservação permanente na bacia hidrográfica do Rio Alegre, Espírito Santo. Ciência Florestal, Santa Maria, v. 15 , n. 2, p. 207-220, 2005.

PELUZIO, T. M. O. et al. Mapeamento de áreas de preservação permanente no ArcGIS 9.3. Alegre: Caufes, 2010. v.1, 58 p.

PINTO, L. V. A. et al. Estudo das nascentes da bacia hidrográfica do Ribeirão Santa Cruz, Lavras, MG. Scientia Forestalis, n. 65, p. 197-206, 2004.

REIS, L. C.; REIS, T. E. S.; SAAB, O. J. G. A. Diagnóstico das áreas de preservação permanente das microbacias hidrográficas do município de Bandeirantes - Paraná. Semina: Ciências Agrárias, Londrina, v. 30, n. 3, p. 527536, jul./set. 2009.

SILVA, S. H. L.; BRAGA, F. A.; FONSECA, A. R. Análise de conflito entre legislação e uso da terra no município de Itabira - MG. Caminhos de Geografia, Uberlândia, v. 11, n. 34, p. 131-144, 2010.

SILVA, A. S. Mineração e áreas de preservação permanentes (APPs) em Santo Antônio De Pádua - RJ. Sociedade e Natureza, Uberlândia, v. 23 n. 2, p. 173-185, mai/ago. 2011.

SOARES, V. P. et al. Mapeamento das áreas de preservação permanente e dos fragmentos florestais naturais como subsidio à averbação de reserva legal em imóveis rurais. Cerne, Lavras, v. 17, n. 4, p. 555-561, out./ dez. 2011.

SPAROVEK, G. et al. Computer assisted Koeppen climate classification: a case study for Brazil. International Journal of Climatology, Malden, v. 27, p. 257-266, 2007. 